\title{
Literary History and Reception Study
}

Literary history has been much too busy trying to prove that past writers shouted loud enough to be heard by posterity. We should be more interested in knowing how far their voices carried in their own generation, and-equally important-whether their generation talked back.

-William Charvat, "Literary Economics and Literary History"

As the mediating, long-forgotten element in literary history, the reader can no longer be ignored.

- Hans Robert Jauss, "Theses on the Transition from the Aesthetics of Literary Works to a Theory of Aesthetic Experience"

The Literary History of the United States has gone through four editions since its first publication in $194^{8}$, and these editions, the latest in 1974 , testify to the staying power of a once dominant approach to doing American literary history. The introduction to LHUS summarizes the approach succinctly: "History as it is written in this book will be a history of literature within the margins of art but crossing them to follow our writers into the actualities of American life. It will be a history of the books of the great and the near-great writers in a literature which is most revealing when studied as a by-product of American experience." In his review of the first edition, René Wellek took issue with the kind of extrinsic literary history implied by this introductory statement. He wrote that "the most serious

1. "Address to the Reader," in Literary History of the United States, vol. 1, ed. Robert E. Spiller et al. (New York: Macmillan, 1948), p. xvii. New one-volume editions of LHUS were published in 1953, 1963 , and 1974 . 


\section{Interpretive Conventions}

deficiency" of LHUS was its "failure to provide a continuous and coherent history of poetic styles, prose-genres, devices and techniques-in short, a history of literature as art." ${ }^{2}$ In place of an account that emphasized political, cultural, and intellectual backgrounds, Wellek and others argued for an "internal literary history," one that stressed "the development of literature as literature."3

Aspects of this intraliterary project have since become essential to doing American literary history. Many journals now routinely publish detailed accounts and analyses of traditions, devices, and genres. Descriptions of "traditional conventions" maintain a prominent place within this intrinsic literary history. Before questioning this now established approach, let me illustrate its activities by discussing the traditional literary conventions Stephen Crane used and modified in writing The Red Badge of Courage.

\section{Conventions and American Literary History}

Crane composed The Red Badge of Courage as an ironic tale of a young soldier's egotistical self-deceptions. To accomplish this portrayal, he showed Henry Fleming to be as deluded in his attitude toward his heroic acts as he was in his earlier rationalizations about running from battle. Throughout the story, the narrator consistently undercuts Henry's unfailing egotism, both his lack of concern for others and his belief in his own uniqueness (either as victim or prophet). The novel concludes with a masterfully ironic coda in which Henry's final evaluation of his past conduct appears as just one more self-delusion. This is the Red

2. René Wellek, "The Impasse of Literary History," Kenyon Review, 11 (1949), 504.

3. René Wellek, "The Concept of Evolution in Literary History," in his Concepts of Criticism, ed. Stephen G. Nichols (New Haven: Yale University Press, 1963), p. 52; Wellek (with Austin Warren), Theory of Literature (New York: Harcourt, Brace, 1949), p. 255. Also see the following: Norman Holmes Pearson's statement that the "most useful referent" of literary history is "the individual and traditional forms making up the body of literature which it studies": "Literary Forms and Types; or, A Defense of Polonius," in English Institute Annual, 1940 (New York: Columbia University Press, 1941), p. 66; Cleanth Brooks's prediction that "the new history of literature should be more truly a history of literature: 
Badge that Crane wrote. However, it is not the book that $\mathrm{D}$. Appleton \& Co. published in October 1895 . A cut-down version of Crane's final manuscript, the text of the Appleton first edition resulted from wholesale expurgations but no extensive rewriting.

Appleton did not print several passages that can still be found in the extant pages of Crane's final manuscript as well as others that existed on pages now missing. Crane marked some of these deletions in the manuscript itself; for example, he crossed out passages at the ends of chapters 7,10 , and ${ }_{15}$ in pencil or blue crayon and removed the folio pages of chapter 12. Other passages (such as those in chapters 16 and 25) were left uncanceled in the manuscript but were not published in the first edition. ${ }^{4}$ Crane cut all this material from the story at the insistence of his Appleton editor, Ripley Hitchcock. ${ }^{5}$ The result was a radically different story from the one Crane had originally written. The Appleton Red Badge seems to present a realistic account of a young soldier's growth to maturity.

Henry Binder has recently demonstrated that Crane's most complete intentions are realized more fully and more consistently in the final manuscript than in the Appleton first edition. Binder is especially effective in showing the incoherence of the Appleton final chapter, the section that most critics use as crucial

that is, it should be better able to deal with literary structures and modes more closely than have the literary histories of the past": The Well Wrought Um (1947; New York: Harcourt, Brace, 1975), p. 238; and R. S. Crane's advocacy of a "narrative history of forms" in his Critical and Historical Principles of Literary History (Chicago: University of Chicago Press, 1971)-this essay was written in $195^{\circ}$ but remained unpublished for seventeen years, according to Sheldon Sacks, "Foreword," p. 5.

4. Most of the manuscript is preserved in the Stephen Crane Collection of the Clifton Waller Barrett Library at the University of Virginia, and four pages of the original chapter 12 are distributed among the Houghton Library at Harvard, the Butler Library at Columbia, and the Berg Collection at the New York Public Library. The final manuscript and an earlier draft are reproduced in The Red Badge of Courage: A Facsimile of the Manuscript, ed. Fredson Bowers, vol. II (Washington, D.C.: NCR/Microcard, 1972).

5. See Henry Binder's convincing argument in "The Red Badge of Courage Nobody Knows," Studies in the Novel, 10 (1978), 17-23. Also cf. Donald Pizer, "The Red Badge of Courage Nobody Knows: A Brief Rejoinder," Studies in the Novel, 11 (1979), 77-81, and Henry Binder, "Donald Pizer, Ripley Hitchcock, and The Red Badge of Courage," Studies in the Novel, 11 (1979), $216-23$. 


\section{Interpretive Conventions}

proof that Henry Fleming has undergone a change in character. Binder illustrates how the referents for key words and passages are illogically missing and how important characters lose their original functions because of the cuts. What he proves quite decisively is that "the excisions were perfunctorily made by a process of cutting out large or small pieces and splicing loose ends together with almost no attempt at rephrasing places where the deletions left the text obscure or incomplete." ${ }^{\theta}$ As a result of his study, Binder decided to follow Hershel Parker's suggestion and reconstruct the version of Red Badge presented in the final manuscript. ${ }^{7}$ This new critical edition of Crane's novel is now available in The Norton Anthology of American Literature. ${ }^{8}$

There are, then, two texts currently called The Red Badge of Courage. The reconstruction of the final manuscript is the version closest to Crane's most complete intentions, but reprints based on the expurgated Appleton first edition contain the version most widely read. Both of these texts can be located in the tradition of the nineteenth-century war novel, as an examination of the traditional conventions of that genre will show.

The historical romance dominated war fiction during the first half of the nineteenth century. ${ }^{9}$ Most historical romances pictured war as an idealized setting for attaining glory. They gave officers the roles of courageous heroes and relegated the common soldier to accepting his patriotic duty and the authority of those over him. If any barbarity tainted the battle descriptions, it was used to show the enemy's cruelty. ${ }^{10}$ These conventions persisted throughout the nineteenth century. But after the Civil

6. Binder, "The Red Badge Nobody Knows," p. 17.

7. Hershel Parker, rev. of The Red Badge of Courage: A Facsimile Edition of the Manuscript and the Virginia edition of Red Badge, Nineteenth-Century Fiction, 30 $(1976), 562$.

8. Ed. Ronald Gottesman et al. (New York: Norton, 1979), II, pp. 802-9o6.

9. Typical American examples were James Fenimore Cooper's The Spy (1821) and William Gilmore Simms's romances of the Revolutionary War $\left(1835^{-56)}\right.$. See Wayne C. Miller's useful study, An Armed America, Its Face in Fiction: A History of the American Military Novel (New York: New York University Press, 1970), Ch. 1.

10. Such was the case in John Esten Cooke's Surry of Eagle's-Nest: or, The Memoirs of a Staff-Officer Serving in Virginia, a 1866 romance which also contained another popular traditional convention, the romantic love interest. See Miller, An Armed America, pp. 82-83. 
War many war novels began modifying the conventions, presenting in particular more realistic detail among the romantic idealizations. ${ }^{11}$

A departure from all variations on the historical romance was the realisitic war novel, which made its appearance with Tolstoy's Sebastopol (1854-55; English translation, 1887). This kind of antiromance idealized neither war nor combatant. A fallible antihero, the common soldier, replaced the traditionally courageous officer of historical romance. At the opening of a typical realistic war novel, the central character often appeared vainglorious, and the traditional martial attitudes of romance were sometimes parodied. Surrounded by the brutality of warfare, the youthful "hero" showed himself afraid in battle and only later became brave; he did not come to war with inborn courage but acquired it in the heat of battle. The realistic war novel thus established a new genre plot convention: growth from cowardice and inexperience to courage and manhood. As Eric Solomon has observed, "By the time American novelists began writing about the Civil War, a European tradition of irony and realism, and a motif of the development, through war, from innocence to maturity, had been established through the war fiction of De Vigny, Stendhal, Zola, and Tolstoy." "I2 In a promotional flyer to book dealers, Appleton directed its edition of Red Badge into this realistic tradition: "For an equally searching and graphic analysis of the volunteer in battle, one is tempted to turn to certain pages of Tolstoy." ${ }^{3}$

The Appleton text of Red Badge does seem to exhibit all of the genre conventions that characterize the realistic war novel typified by Sebastopol. ${ }^{14}$ Henry Fleming is an enlisted man whose

11. "Romanticism" and "realism" are relative terms placed along a spectrum of verisimilitude with abstract stylization and idealization near one end and photographic realism near the other, the values along the spectrum being defined by conventional agreement. Another way of putting this is to say that realism, like romanticism, is a modal convention. See Douglas Hewitt's description of this convention quoted above, in Ch. 5, p. 131 .

12. Eric Solomon, Stephen Crane: From Parody to Realism (Cambridge: Harvard University Press, 1966), p. 69 .

13. This bookseller's order blank, discovered by Henry Binder, is reprinted in Studies in the Novel, 10 (1978), 4-5.

14. See Lars Åhnebrink, The Beginnings of Naturalism in American Fiction 


\section{Interpretive Conventions}

romantic visions of war ("a Greeklike struggle") are soon dispelled in the actualities of combat. At the outset he dreams of heroic accomplishments but then feels grave doubts about his ability to act courageously in battle. As it turns out, he stands and returns fire during the first attack only to flee in terror during the second. Then after wandering for some time in the woods, he is returned to his regiment by a stranger and fights courageously the next day, becoming the company flag-bearer. In the final chapter, Henry feels "a quiet manhood, nonassertive but of sturdy and strong blood." 15

On the basis of the Appleton text, most contemporary reviewers saw Red Badge as a realistic war novel in the tradition of Tolstoy, perhaps exceptional in its psychological realism or impressionistic style but wholly traditional in its use of the convention of initiation and growth in its young hero. However, the maimed state of the Appleton text did not allow reviewers and later critics to see the originality of what Crane had actually written. The manuscript version is antiromantic, but it is also the ultimate extension of ironic realism in that it rejects the convention of initiation. In the manuscript Henry experiences no growth, no movement from innocence to maturity or illusion to enlightenment. Certain passages not published in the Appleton first edition clearly indicate that Henry has learned nothing by the end of the novel. ${ }^{16}$ There were obvious precedents for the story told in the Appleton text within the tradition of nineteenth-century war fiction, but what Crane wrote in the

(Cambridge, 1950; rpt. New York: Russell \& Russell, 1961), pp. 344-6o; and J. C. Levenson, Introduction to The Red Badge of Courage: An Episode of the American Civil War, ed. Fredson Bowers (Charlottesville: University Press of Virginia, 1975), pp.xl-xlvi.

15. Stephen Crane, The Red Badge of Courage: An Episode of the American Civil War (New York: Appleton, 1895), p. 232. A facsimile of the first impression of the Appleton first edition has been published by Charles E. Merrill Publishing Co. (Columbus, O., 1969), introduced by Joseph Katz.

16. The most significant deletions included passages referring to Henry's propensity for self-delusion portrayed in cosmic terms (final manuscript pp. 188, $191-92)$; the words that show Henry thinking that death was only "for others" (final manuscript p. 192); and the last Jimmie Rogers episode which exposed Henry's continued egotism (final manuscript p. 187). See Binder, "The Red Badge Nobody Knows," pp. 27-31. 


\section{Literary History and Reception Study}

manuscript transcends the tradition. The manuscript indicates that Crane's original conception was truly unique, reacting against both the historical romance's idealization of war and the realistic novel's convention of successful initiation.

\section{Aesthetics of Reception}

The foregoing discussion closely resembles the traditional discourse of intrinsic literary history. It takes a text and locates it in the developing context of a literary movement (realism) and a narrative genre (the war novel). Such a historical placement is usually the first step in any literary history, and this is often as true for extrinsic literary histories as it is for intrinsic accounts. ${ }^{17}$ A study like The Machine in the Garden illustrates this last point nicely. ${ }^{18}$ In writing his cultural history, Leo Marx set out to discover responses to industrialization in nineteenth-century American literature and found the recurrent use of a contrast between machine and natural landscape. However, before investigating further the "interplay between literature and the extraliterary experience of the age," Marx had to decide how this interplay was affected by the "interior history of literature itself." He therefore examined the tradition of the pastoral, "the interior development of its forms and conventions." He concluded that "the conventional features of a work must be acknowledged and understood before the cultural historian can answer such important questions as: what made the convention relevant at the time? what modifications did the age make in the conventions? how can the modifications be explained?" 19 Here Marx affirms that intrinsic literary history, as an account of traditional conventions, must precede the kind of extraliterary investigation he wished to pursue.

17. René Wellek writes that the "establishment of the exact position of each work in a tradition is the first task of literary history" (Theory of Literature, p. 249).

18. Leo Marx, The Machine in the Garden: Technology and the Pastoral Ideal in America (New York: Oxford University Press, 1964). I have chosen to use Marx's book as an example of extrinsic approaches primarily because of some excellent observations he makes on his study in "American Studies-A Defense of an Unscientific Method," New Literary History, 1 (1969), 75-90.

19. Marx, "American Studies," pp. 85-86. 


\section{Interpretive Conventions}

Such intrinsic and extrinsic literary histories are illuminating as far as they go. But unfortunately they do not go far enough. What these accounts conceal is the interpretive work of readers and critics that constitutes the basis of all literary history. Such traditional histories ignore what Ingarden called the different "concretizations" of a literary work, that is, the various realizations which arise from individual readings of the text throughout its history. Ingarden spoke of the "life" of a literary work as being "in its concretizations." ${ }^{20}$ Recognition of this "life" calls for a different kind of intrinsic and extrinsic literary history, one that places the reader at the center of historical research. In other words, the traditional history of production must be supplemented by a history of literary reception.

In the Theory of Literature, Wellek (influenced by Ingarden) had in fact acknowledged the importance of both histories when he described the two tasks of literary historians: the "tracing of the development of works of art" in terms of genres, styles, and the like, and the description of the historical "process of interpretation, criticism, and appreciation" of the work's structure which changes "while passing through the minds of readers, critics, and fellow-artists." ${ }^{21}$ In this definition of tasks, Wellek gives equal importance to histories of production and reception. However, the history of production completely dominates his general discussion of literary history and has always done the same in actual histories of American literature. Accounts of reception have usually been relegated to the history of taste, which is ultimately seen as secondary, even marginal, within American literary study. ${ }^{22}$

German aesthetics of reception has recently proposed an alternative to the production model of traditional literary history.

20. Roman Ingarden, The Literary Work of Art, trans. George G. Grabowicz (Evanston: Northwestern University Press, 1973), p. $35^{\circ}$.

21. Wellek, Theory of Literature, pp. 244-45.

22. This does not mean that American literary study has produced no useful reception histories. It does mean that such histories ( 1 ) are often treated as being of minor importance and (2) are usually written with no self-consciousness about the historical conditions of reception. The most significant exception to (2) is Michael Meyer, Several More Lives to Live: Thoreau's Political Reputation in America (Westport, Conn.: Greenwood Press, 1977). 
This Rezeptionsästhetik stresses "the dialectical unity of production and reception," ${ }^{23}$ writes Peter Hohendahl; but it emphasizes even more the neglected pole of this dialectic, the process of reception or consumption. "Just as production mediates consumption-in the area of supply, distribution, and formation of attitude in the recipient-so does consumption mediate production: the reader's concretization transforms a model into a living work, and those needs of the public articulated in the reception condition the direction and extent of literary production."24 American literary history has generally ignored this dialectic between the author and his reading public. William Charvat's outstanding study, The Profession of Authorship in America, $1800-1870$, is the proverbial exception that proves the rule of a production-centered tradition in American literary history. ${ }^{25}$

Hans Robert Jauss has stated the case for an alternative tradition most forcefully: "If literary history is to be rejuvenated, the prejudices of historical objectivism must be removed and the traditional approach to literature must be replaced by an aesthetics of reception and impact." ${ }^{26}$ The most important assumption of this Rezeptionsästhetik is its belief in the openness of the literary text. As Jauss puts it, "A literary work is not an object which stands by itself and which offers the same face to each reader in each period." He rejects the claims "that literature is timelessly present and that it has objective meaning, determined once and for all and directly open to the interpreter."27 Instead, he and others in reception aesthetics take very seriously Ingarden's con-

23. Peter Uwe Hohendahl, "Introduction to Reception Aesthetics," New German Critique, No. 10 (1977), p. 56.

24. Ibid., p. 62. Cf. Hans Robert Jauss, "Theses on the Transition from the Aesthetics of Literary Works to a Theory of Aesthetic Experience," in Interpretation of Narrative, ed. Mario J. Valdés and Owen J. Miller (Toronto: University of Toronto Press, 1978), p. 138.

25. William Charvat, The Profession of Authorship in America, $1800-1870$, ed. Matthew J. Bruccoli (Columbus: Ohio State University Press, 1968). See also Charvat, Literary Publishing in America, 1790-1850 (Philadelphia: University of Pennsylvania Press, 1959).

26. Hans Robert Jauss, "Literary History as a Challenge to Literary Theory," New Literary History, 2 (1970), 9.

27. Ibid., pp. 10, 19. Also see “Interview/Hans R. Jauss,” Diacritics, 5, No. 1 (1975), 53 . 


\section{Interpretive Conventions}

cept of concretizations. ${ }^{28}$ Different concretizations are allowed by the "fundamental openness of literary texts ... which forms the basis for the concept and the process of reception." 29

Reception aesthetics assumes a text's fundamental openness and focuses on the history of concretizations this openness permits. Of course, the "historical life of a literary work is unthinkable without the active participation of its audience."30 A second basic assumption of Jauss's Rezeptionsästhetik is that readers' "horizons of expectations" determine their active participation. According to Jauss, the response and impact of a literary work should be described "within the definable frame of reference of the reader's expectations: this frame of reference for each work develops in the historical moment of its appearance from a previous understanding of the genre, from the forms and themes of already familiar works, and from the contrast between poetic and practical language." The third factor he lists "includes the possibility that the reader of a new work has to perceive it not only within the narrow horizon of his literary expectations but also within the wider horizon of his experience of life." ${ }^{31}$

Jauss's theory of reception, then, recognizes both intra- and extraliterary horizons of expectations. The intraliterary horizon

28. In fact, the aesthetics of reception takes the concept more seriously than did Ingarden. For example, Jauss uses Felix Vodička's version of the concept, and Vodička has "historicized" Ingarden's use of it. According to Ingarden, "the work, in the polyphonic harmony of its qualities, still had the character of a structure independent of temporal changes in the literary norm; but Vodička disputes the idea that the esthetic values of a work could be given complete expression through an optimal concretization": Jauss, "History of Art and Pragmatic History," in New Perspectives in German Literary Criticism: A Collection of Essays, trans. David Henry Wilson et al., ed. Richard E. Amacher and Victor Lange (Princeton: Princeton University Press, 1979), p. 461. Cf. the critique of Ingarden in Hohendahl, "Introduction to Reception Aesthetics," pp. $33-35$, and see above, Ch. 2 , p. $5^{2}$.

29. D. W. Fokkema and Elrud Kunne-Ibsch, Theories of Literature in the Twentieth Century: Structuralism, Marxism, Aesthetics of Reception, Semiotics (New York: St. Martin, 1977). p. 158 .

3o. Jauss, "Literary History," p. 8.

31. Ibid., pp. 1 1, 14. Cf. the concept of "horizon" in Hans-Georg Gadamer, Truth and Method (original German ed. 1960; 2d ed. 1965; English trans. London: Sheed \& Ward, 1975), pp. 269-7o. Jauss carefully notes similarities and differences between his and Gadamer's use of "horizons" in their theories (“Literary History," pp. 20-23). 
is the background of genres, forms, and themes against which a text is read at any historical moment. The text can either fulfill or disappoint these expectations, and if it disappoints, it can help change the content of the horizon. The extraliterary horizon of social expectations also influences reception and impact; and as with the intraliterary, the effect of literature can change the extraliterary horizon as well. It is this power to change social expectations that defines "the society-forming function of literature" for Jauss. "The horizon of expectations of literature is differentiated from the horizon of expectations of historical life by the fact that it not only preserves real experiences but also anticipates unrealized possibilities, widens the limited range of social behavior by new wishes, demands, and goals, and thereby opens avenues for future experience."32 Literature changes society by changing readers' social expectations.

Reception aesthetics as a whole stresses the interdependence of the intra- and extraliterary horizons of expectations. The histories of reception that result from this stance are analogous (and complementary) to the combination of intrinsic and extrinsic forms of traditional literary history. What would a parallel to an exclusively intrinsic literary history look like and what purpose would such intraliterary reception studies serve? The analyses in the next two sections will answer this question. In these analyses, the emphasis is not on the political or cultural constraints on reading and criticism nor on the effects of literature on society, but rather on the literary conventions that influence evaluation and interpretation. In the same way that intrinsic literary history precedes (but does not replace) extrinsic accounts, the reception study I propose is assumed by Rezeptionsästhetik.

The two kinds of interpretive work I describe underlie the various literary histories now being written, both traditional accounts of production and newer accounts of reception. For between the text's production and its impact in reception stands its interpretation by readers and critics. As we have seen, interpretive conventions determine the shape and content of this initial

32. Jauss, "Literary History," pp. 32-33. He further clarifies his notion of "horizon of expectations" in "Theses," pp. 140-42. 


\section{Interpretive Conventions}

step in literary consumption. Traditional literary history completely ignores this interpretive work by readers and critics when it locates conventions in texts that are viewed as stable and fixed in writing for all time. Literary conventions thus play merely a passive role: readers and critics must simply recognize them, and literary historians need only pick them out and place them in the context of movements, genres, and periods as they build up their historical accounts. Traditional literary history pays no attention to the active role played by conventions in evaluation and interpretation during different historical periods. Even current histories of reception often emphasize the effect of the text's meaning and value rather than the interpretive activity that produces that meaning and value. For example, in reconstructing the horizon of social norms for a group of French lyrics of 1857 , Jauss discusses the effect of their reception on the socialization process in bourgeois society; but his "horizon analysis" leaves completely unexplained the interpretive work of readers that would have to be performed before such a socialization effect could take place. ${ }^{33}$

To uncover this concealed hermeneutic activity in literary history, I will examine two instances of reception. The first demonstrates how traditional conventions can become prescriptive or evaluative, a fact that accounts for a curious difference between the initial American and British responses to Melville's MobyDick. In the second example, I analyze the critical history of the Appleton Red Badge of Courage. The reception of this text is an especially clear illustration of disguised interpretive work because the text is incomplete and must obviously be supplemented by its readers before its meaning can be discovered. Here traditional literary conventions become constitutive conventions.

\section{Traditional Conventions as Prescriptive}

While working on his sixth book, Herman Melville wrote to his friend, Evert Duyckinck, "I don't know but a book in a man's

33. Jauss, "La Douceur du Foyer: The Lyric of the Year 1857 as a Pattern for the Communication of Social Norms," Romanic Review, 65 (1974), 201-29. 


\section{Literary History and Reception Study}

brain is better off than a book bound in calf-at any rate it is safer from criticism." 34 Despite such wry protestations, Melville allowed Bentley to publish The Whale in London on 18 October $18_{5} 1$; and Harpers published Moby-Dick; or The Whale in New York around 14 November. ${ }^{35}$ The title was not the only difference between the first English and American editions. The "Etymology" and "Extracts" appeared in an "Appendix" after the final chapter in the third volume of the English edition, rather than at the beginning of the book as in the American. More important to the critical reception were the alterations made in the American proofs from which the English edition was set. Besides Melville's own revisions of the proofs he sent to England, Bentley or his reader also made several changes in the text: deleting Chapter 25 for its disrespect toward royalty; changing "God" to "G-d" and "damn" to "d-n"; and expurgating passages considered irreverent or indecent. Because they worked with the unexpurgated version, the American reviewers criticized Melville much more often than did their British counterparts for the "indelicacies" and "profane jesting" in his book. Also crucial to the critical response was the epilogue missing from the first English edition. Still, these textual variations alone do not explain all the differences between the American and the British evaluations of Melville's novel. To locate one of these differences and its specific causes, I must first outline the general critical reception given the book on both sides of the Atlantic. Such a survey is needed to counteract past claims about a predominantly negative reaction from contemporary reviewers. ${ }^{36}$

34. Letter dated 13 December $185^{\circ}$, in The Letters of Herman Melville, ed. Merrell R. Davis and William H. Gilman (New Haven: Yale University Press, 1960), p. 117 .

35. See Jay Leyda, The Melville Log, vol. I (New York: Harcourt, Brace, 1951; rpt. with supplement, New York: Gordian Press, 1969), pp. 430, 433.

36. See, for example, John Freeman, Herman Melville (London: Macmillan, 1926), p. 130; O. W. Riegel, "The Anatomy of Melville's Fame," American Literature, 3 (1931), 196; F. O. Matthiessen, American Renaissance (New York: Oxford University Press, 1941), p. 251, n. 5; Alexander Cowie, The Rise of the American Novel (New York: American Book, 1948), p. 384; Howard P. Vincent, The Trying-Out of Moby-Dick (Boston: Houghton Mifflin, 1949), p. 3; and Alan Wykes, A Concise Survey of American Literature (New York: Library Pub., 1955), p. 70. Willard Thorpe was one of the first modern scholars to debunk this "legend that 


\section{Interpretive Conventions}

The response to The Whale and Moby-Dick actually ranged from enthusiastic praise to extravagant condemnation in both England and America. Two of the most influential British papers, the Athenaeum and the Spectator, were highly critical in their comments, while Blackwood's apparently ignored The Whale entirely. The Athenaeum bluntly indicated its displeasure with Melville's performance: "Our author must be henceforth numbered in the company of the incorrigibles who occasionally tantalize us with indications of genius, while they constantly summon us to endure monstrosities, carelessness, and other such harassing manifestations of bad taste as daring or disordered ingenuity can devise." 37 Melville's "extravagances," his "raving and rhapsodising" were favorite targets for the London Morning Chronicle and others: "mad (rather than bad) English," complained the Athenaeum (p. 7). However, opposed to such censure were reviews like the one in John Bull: "few books which professedly deal in metaphysics, or claim the parentage of the muses, contain as much true philosophy and as much genuine poetry as the tale of the Pequod's whaling expeditions" (p. 9). The London Morning Post sounded even more enthusiastic: "we cannot hesitate to accord to Mr. Melville the praise of having produced one of the cleverest, wittiest, and most amusing of modern books" ( $p$. 30). The London Morning Advertiser went so far as to claim that no work "more honourable to American Literature" had "yet reflected credit on the country of Washington Irving, Fenimore Cooper, Dana, Sigourney, Bryant, Longfellow, and Prescott" (p. 7). An examination of the other known English reviews simply confirms this picture of a radically divided opinion of The Whale, high praise on the one hand, violent attack on the other.

Unlike their British counterparts, the majority of American reviews were very brief notices, many giving no evidence of a close or even complete reading of Moby-Dick. The longer reviews and the more perceptive shorter ones appeared just as divided

the reviewers demolished Moby-Dick," in his "Introduction" to Herman Melville: Representative Selections (New York: American Book, 1938), p. cxxii.

37. Rpt. in Moby-Dick as Doubloon, ed. Hershel Parker and Harrison Hayford (New York: Norton, 1970), p. 8. Page citations in the text of this section refer to Doubloon. 
in their evaluations as the British notices. The Literary World pronounced Moby-Dick "a most remarkable sea-dish" (p. 49), while the Spirit of the Times called it "a work of exceeding power, beauty, and genius" (p. 64). "It will add to Mr. Melville's repute as a writer, undoubtedly," wrote the Evangelist (p. 41). In contrast, To-day complained, "the book appears to us rather drawn out, and could easily afford considerable paring down" (p. 86). The strongest criticism came from the Democratic Review, which concluded its comments: "if there are any of our readers who wish to find examples of bad rhetoric, involved syntax, stilted sentiment and incoherent English, we will take the liberty of recommending to them this precious volume of Mr. Melville's" (p. 84).

This brief survey of contemporary reviews presents only part of the available evidence disproving those twentieth-century accounts which assumed that Melville's novel was a critical failure at its birth. ${ }^{38}$ The true picture shows a more positive and more divided critical reception. Though similar in their split opinions, American and British reviewers differed in their reasons for praise and blame. One difference followed from the British reviewers' greater professionalism, which gave their comments a sophistication and precision found in only a few American notices. This distinction between the two groups of critics had a rather curious (and as yet unexplained) consequence: the British reviewers' professionalism sometimes prejudiced their comments on The Whale as much as it benefited them. ${ }^{39}$ How exactly did this happen?

38. Earlier corrections in addition to Thorpe's, can be found in David Potter, "Reviews of Moby-Dick," Journal of the Rutgers University Library, 3 (1940), 62-65; John C. McCloskey, "Moby Dick and the Reviewers," Philological Quarterly, 25 (1946), 20-31; and Hugh W. Hetherington, "Early Reviews of Moby-Dick," in Moby-Dick Centennial Essays, ed. Tyrus Hillway and Luther S. Mansfield (Dallas: Southern Methodist University Press, 1953), pp. 89-122. The most complete surveys of the contemporary reception are Hugh W. Hetherington, Melville's Reviewers (Chapel Hill: University of North Carolina Press, 1961), and Hershel Parker's section of the "Historical Note" in the forthcoming NorthwesternNewberry edition of Moby-Dick.

39. Of course, calling some British reviewers "prejudiced" here is a function of the twentieth-century reevaluation of Moby-Dick. That is, Melville's novel is a "masterpiece" only in relation to our present horizon of expectations, just as the British evaluations were determined by their horizons. 


\section{Interpretive Conventions}

The British critics were guided by tested literary standards, based on a thorough knowledge of traditional literary conventions. ${ }^{40}$ For some, this descriptive knowledge rigidified into prescriptive rules; traditional conventions became regulative. The advantage of such literary prescriptions was that a reviewer could more clearly and rigorously specify the faults of inartistic works. But in cases of unprecedented masterpieces, these conventional precepts failed. ${ }^{41}$

There was, then a built-in conservatism in some British evaluations of The Whale due to the use of these traditional conventions turned prescriptive. For example, the Athenaeum could not tolerate the untraditional combination of extravagant adventure story and technical whaling information, a combination which it called "an ill-compounded mixture of romance and matter-offact." To explain its criticism, the Athenaeum gave first a general precept, "There is a time for everything in imaginative literature;--and according to its order, a place-for rant as well as for reserve"; then its specific objection followed: "The voice of 'the storm wind Euroclydon' must not be interrupted by the facts of Scoresby and the figures of Cocker. Ravings and scraps of useful knowledge flung together salad-wise make a dish in which there may be much surprise, but in which there is little savour" (p. 7). The Spectator proceeded in a similar fashion, first giving

40. Cf. Hetherington, Melville's Reviewers, p. 14: "The British reviewers tended to be more thorough and analytical, to be more concerned with aesthetic values, to be more aware of literary conventions."

41. This fact supports Jauss's claim that the "aesthetic value" of a literary work resides in the extent it challenges the contemporary horizon of expectations; see Jauss, "Literary History," p. 14. However, Jauss does not stress that a text can challenge expectations and still be considered worthless later; e.g., novels by Melville's fellow Young American, Cornelius Mathews, certainly challenged contemporary expectations about American novels, but his books are still considered failures today. The crucial point is not simply whether a work challenges contemporary expectations, but whether such a challenge is valued in later horizons of expectations. This is the case for Moby-Dick, whose 1850 os reception was rejected by twentieth-century critics. These later critics differed from nineteenth-century reviewers not only because they utilized different regulative conventions (e.g., about indecency and blasphemy in fiction writing), but also because they used different traditional conventions: Moby-Dick became a brilliant example of a new horizon of intraliterary expectations for the novel, instead of a rejected transgression against the old horizon, as it was for some contemporary British reviewers. 


\section{Literary History and Reception Study}

the regulative convention and then Melville's transgression: "It is a canon with some critics that nothing should be introduced into a novel which it is physically impossible for the writer to have known.... Mr. Melville hardly steers clear of this rule"; then it added, "and he continually violates another, by beginning in the autobiographical form and changing ad libitum into the narrative" (p. 12). The London Examiner complained that "all the regular rules of narrative or story are spurned and set at defiance. For a great part of the book it is Ahab the captain monologuizing in a wild mad way; then it is the seaman Ishmael; and then Mr. Melville himself." The reviewer then observed that it is Melville "who has kindly taken up the narrative which must otherwise have gone to the bottom with Ishmael and everybody else concerned" (pp. 24-25). Indeed, the unintentional absence of the epilogue in The Whale certainly added to the dissatisfaction with "rule-breaking" on Melville's part. The Spectator, New Quarterly Review, and Dublin University Review all noticed the inconsistent ending. The remark of the Literary Gazette was typical: "How the imaginary writer, who appears to have been drowned with the rest, communicated his notes for publication to $\mathrm{Mr}$. Bentley is not explained" (p. 61).

The British preoccupation with literary conventions led them naturally to ask: In what traditional genre should The Whale be placed? Since three-decker novels were common, the Literary Gazette thought that the book was "professing to be a novel" (p. $60)$. With a similar assumption, the Britannia wrote that it was "at a loss to determine in what category of works of amusement to place it. It is certainly neither a novel nor a romance, although it is made to drag its weary length through three closely printed volumes, and is published by Bentley, who, par excellence, is the publisher of the novels of the fashionable world, for who ever heard of novel or romance without a heroine or a single love scene?" (p. 22). Similarly, the New Quarterly Review observed: "Many, doubtless, will cavil at the application of the term 'novel' to such a production as this, seeing that no tale of love is interwoven with the strange ana of which it is compounded" (p. $7^{8}$ ). The London Morning Chronicle exemplified this bewildered side of the British response when it commented that Melville's book was a "strange conglomeration of fine description, reckless 
fancy, rhapsodic mistiness, and minute and careful Dutch painting" (p. 77). On the other hand, the London Weekly News had no problem categorizing The Whale: it is "the most powerful and original contribution that Herman Melville has yet made to the Romance of Travel" (p. 55). The admiring London Leader was puzzled but not frustrated when it asserted, "The book is not a romance, nor a treatise on Cetology. It is something of both: a strange, wild work with the tangled overgrowth and luxuriant vegetation of American forests, not the trim orderliness of an English park" (p. 26). Perhaps this understated comment from the Dublin University Magazine most typified the reaction of its British counterparts with their concern for traditional and regulative literary conventions: "All the rules which have been hitherto understood to regulate the composition of works of fiction are despised and set at naught. Of narrative, properly so called, there is little or none; of love, or sentiment, or tenderness of any sort, there is not a particle whatever; and yet, with all these glaring defects, it would be vain to deny that the work has interest" (p. 86).

In their analyses of Moby-Dick, most American reviewers were less specific than The Whale's commentators in England. However, because they were also less concerned with literary traditions, they did not become as frustrated with the strange mixture of genres that made up Melville's masterpiece. In fact, the imaginative American labels for Moby-Dick seem a celebration of its diversity. "Such a salmagundi of fact, fiction and philosophy, composed in a style which combines the peculiarities of Carlyle, Marryatt and Lamb, was never seen before," exclaimed the New York Commercial Advertiser (p. 53). The Literary World called Moby-Dick "an intellectual chowder of romance, philosophy, natural history, fine writing, good feeling, bad sayings" (pp. 49-5o). "It appears to be a sort of hermaphrodite craft-half fact and half fiction," wrote the Boston Evening Traveller in a brief approving notice (p. 32). The New York Daily Tribune coined the term "Whaliad" for what the Washington National Intelligencer called "a prose Epic on Whaling" (pp. 47, 68). Finally, Harper's New Monthly Magazine labeled Moby-Dick "a romance, a tragedy, and a natural history, not without numerous gratuitous suggestions on psychology, ethics, and theology. Be- 
neath the whole story, the subtle, imaginative reader may perhaps find a pregnant allegory, intended to illustrate the mystery of human life" (p. 57).

Not preoccupied by the literary precepts of the British professionals and having the "Epilogue" in their edition, the American reviewers made no complaints about Melville's "violation" of conventional narrative rules. The only two American reviewers to raise the issue at all did not allow traditional-turnedprescriptive conventions to dominate their evaluations of Melville's unique work. Noting that "no man can serve two masters, even in fiction," the reviewer for Peterson's felt that the "philosophical romance" had spoilt "a skilfully told narrative of sea-adventures." But he added: "Still the demerit of 'Moby-Dick' is only comparative. It is not an indifferent work, but a very superior one, after all" (p. 84). This prescriptive restraint was even better illustrated by the sophisticated critic of the Washington National Intelligencer: "Nor do we propose ... to haul Mr. Herman Melville over the coals for any offences committed against the code of Aristotle and Aristarchus: we have nothing to allege against his admission among the few writers of the present age who give evidence of some originality" (p. 66). Though the American reviewers critical of Moby-Dick found reasons to justify their critiques, traditional conventions turned prescriptive were certainly not among them.

What we find illustrated in the contrast between these British and American reviews is one reception in which traditional conventions became prescriptive (and thus evaluative) and another reception in which they did not. But the exact way conventions worked in the British judgments needs a bit more specification. The British use of these regulative conventions accomplished very economically the two movements of evaluation: making precise distinctions within a work and at the same time raising the work to the level of abstraction or general value-in the words of one recent theorist, "moving simultaneously to finer points with reference to the text and more abstract points with reference to the value of the text." 42 Through traditional-

42. Susan Stewart, "Some Riddles and Proverbs of Textuality: An Essay in Literary Value and Evaluation," Criticism, 21 (1979), 103. 
turned-prescriptive conventions, British reviewers could define exactly how a new book worked (or didn't work) and how it succeeded (or failed) in its general relation to the established canon. Here the act of evaluation reveals itself as a consequence of interpretation. Evaluation follows from the translation of the work from one context (the analyzed specifics of a text's dynamics) to another context (the text in relation to a valued set of traditional conventions); and interpretive work is clearly involved both in the analysis of the text and in the placement of the analyzed work in the context of literary history. Thus in the British reviews of The Whale, evaluation becomes a complex extension of interpretation. ${ }^{43}$

The same extension can be seen if we look at the critical history of the Appleton Red Badge of Courage. In the British reception of The Whale, traditional genre conventions became criteria for evaluation, and Melville's novel was sometimes found wanting. In the case of Red Badge, critics have used traditional modal conventions as evaluative criteria and praised Crane for initiating or perfecting the use of these modal conventionsimpressionism, ironic realism, deterministic naturalism, and modern symbolism. Such modal conventions can be exhibited across different genres, throughout a single text, and even in fragments of texts. This latter fact explains how the expurgated Appleton version could still be widely praised for its impressionism, realism, etc. ${ }^{44}$

But another question arises: What interpretations of Red Badge do such evaluations assume? That is, what holistic meanings have its enthusiastic readers constructed for the Appleton

43. The intraliterary reception study I have presented in this section can be contrasted to examinations of the extraliterary factors affecting the reviews of Melville's novels. See John Stafford, The Literary Criticism of "Young America": A Study in the Relationship of Politics and Literature, I 857-I 850 (Berkeley: University of California Press, 1952), and Perry Miller, The Raven and the Whale: The War of Words and Wits in the Era of Poe and Melville (New York: Harcourt, Brace \& World, 1956).

44. See Edwin H. Cady, Stephen Crane, 2d ed. (New York: Twayne, 1980), pp. 119-40; Donald Pizer, "Stephen Crane," in Fifteen American Authors before I 900 : Bibliographic Essays on Research and Criticism, ed. Robert A. Rees and Earl N. Harbert (Madison: University of Wisconsin Press, 1971), pp. 112-18; and Marston LaFrance, "Stephen Crane Scholarship Today and Tomorrow," American Literary Realism, 7 (1974), 129, $131-33$. 
text? Put even more pointedly: if the Appleton edition is illogical and inconsistent (as Binder has shown), how have Red Badge critics been able to make any sense of it, let alone call it an American classic?

\section{Traditional Conventions as Constitutive}

The following discussion is limited to critical arguments that focus on Crane's use of two genre conventions-growth of protagonist and attitude of narrator toward characters-because most holistic interpretations of Red Badge focus on Crane's use (or misuse) of these conventions. In the course of the discussion, I will show how generic, modal, and authorial conventions constitute the interpretations of the Appleton text. Red Badge criticism clearly illustrates how traditional literary conventions become constitutive conventions: to make sense of the expurgated Appleton text, critics have been forced to rely on conventions of past literary practice to supply the present meaning of an incoherent text.

Critics of Red Badge fall into one of three general categories: (1) those who, seeing few if any interpretive problems, make sense of the Appleton text by concluding that Henry grows and that the narrator's attitude toward him moves from ironic undercutting to various degrees of sympathetic approval; (2) those who cannot make sense of the text because of its apparent contradictions; and (3) those who make sense of the text by concluding that Henry experiences no growth and that the narrator's attitude is consistently ironic.

The overwhelming majority of Red Badge critics fall into the first category; they interpret the Appleton text according to the traditional conventions of the nineteenth-century realistic war novel and therefore see Henry as growing in the course of his war experience. There is, however, an extremely wide divergence of opinion among these critics over the terms of his growth, whether from cowardice to bravery, innocence to experience, or ignorance to insight.

Those critics who believe that Henry grows from a cowardly civilian to a courageous soldier view Red Badge as a war story in its narrowest sense. Most contemporary reviewers belonged to 
this group. For example, in the Saturday Review Sydney Brooks spoke of Henry Fleming as "a raw youth" who "develops into a tried and trustworthy soldier," and the reviewer for The Bookman saw in the novel "a genuine development of the untried civilian into the capable and daring soldier." 45 In his 1925 preface to Red Badge, Joseph Conrad referred to Crane's "war book" and "the problem of courage," seeing Henry as a "symbol of all untried men." ${ }^{46}$ More recently, critics such as Lars Åhnebrink have written of Henry's "development into a real war hero" and about "the process of conquering fear" analyzed in the novel. ${ }^{47}$

A more complex growth in Henry is posited by critics who interpret him as growing in experience from innocence to maturity but make no explicit reference to his gaining selfknowledge. In 1895, William Dean Howells called Henry a "tawdry-minded youth" and praised Crane's skill "in evolving from the youth's crude expectations and ambitions a quiet honesty and self-possesion manlier and nobler than any heroism he had imagined."48 In a similar vein but decades later, V. S. Pritchett wrote about Henry as "a green young recruit" who "loses his romantic illusions and his innocence in battle and acquires a new identity, a hardened virtue." ${ }^{49}$ In 1945 , R. B. Sewall interpreted the ending as a complete "moral victory" for Henry, whose "victory over fear" seems to have made up for his past sins (running from battle and deserting the tattered soldier). However, Sewall was also the first critic to voice objections to the ending of the Appleton text; he found Henry's final "state of

45. "In the School of Battle: The Making of a Soldier," London Saturday Review, 11 January 1896, p. 43; and London Bookman, 9 (January 1896), 131. On the evidence for attributing the Saturday Review notice to Brooks, see Richard M. Weatherford, ed., Stephen Crane: The Critical Heritage (London: Routledge \& Kegan Paul, 1973), p. 99 .

46. Joseph Conrad, "His War Book: A Preface to Stephen Crane's 'The Red Badge of Courage," ' in his Last Essays (Garden City, N.Y.: Doubleday, Page, 1 926), $121-23$. Also see Conrad's earlier comment on Red Badge: "The subject of that story was war, from the point of view of an individual soldier's emotions" ("Stephen Crane: A Note Without Dates," The London Mercury, 1 [December 1919], 192).

47. Åhnebrink, p. 351.

48. Harper's Weekly, 26 October 1895, p. 1013 .

49. V. S. Pritchett, "Two Writers and Modern War," in The Living Novel (London: Chatto \& Windus, 1946), p. 174. 


\section{Literary History and Reception Study}

complacency" to be "undeserved and arbitrary" in terms of "Henry's moral struggle as Crane has represented it." 50

Of recent comments on Red Badge, Donald Pizer's interpretation is the most interesting example from this group of critics who see growth in experience but not necessarily in selfknowledge. For Pizer, Henry "emerges at the end of the battle not entirely self-perceptive or firm-willed-Crane is too much the ironist for such a reversal-but rather as one who has encountered some of the strengths and some of the failings of himself and others." Pizer never specifically states that Henry gains an insight into himself; he only describes the youth's growth negatively-Henry is not the same as he was-and implies that the difference may be limited self-knowledge. Pizer surmises that "something has happened to Fleming which Crane values and applauds," and then suggests that this "something" is partly Henry's movement from isolation to "oneness with his fellows." Whether Pizer thinks Henry himself actually realizes this is not clear: "Henry is still for the most part self-deceived at the close of the novel, but if he is not the 'man' he thinks he has become, he has at least shed some of the innocence of the child." 51 Sensitive to irony as an authorial convention exhibited throughout Crane's canon, Pizer is careful not to claim too much

50. R. B. Sewall, "Crane's The Red Badge of Courage," The Explicator, 3, No. 7 (1945), Item 55 .

51. Donald Pizer, Realism and Naturalism in Nineteenth-Century American Literature (Carbondale: Southern Illinois University Press, 1966), pp. 26-3o. Recognizing that "Fleming's self-evaluations contrast ironically with his motives and actions throughout the novel," Pizer also claims that "Fleming's own sanguine view of himself at the close of the novel-that he is a man-cannot be taken at face value" (p. 28). This last assertion and Pizer's later published comments on Red Badge suggest that the ambiguity I see in his critical text might actually be what he unambiguously saw in Crane's literary text. In "A Primer of Fictional Aesthetics," College English, 30 (1969), Pizer clearly states that "ambivalence dominates the closing portion" of Red Badge and that "the author's evaluation of his central character" is a "mystery" which "is left unsolved at the close of the novel" (pp. $57^{6-77}$ ). In his 1969 review of Crane scholarship, Pizer lists his own interpretation as one of those supporting the thesis that Henry "has gained from his experiences but he is nevertheless deluded in his understanding of what he has gained" (Pizer, "Stephen Crane," p. 125). And in "The Red Badge Nobody Knows: A Brief Rejoinder," Pizer supports interpretations that see the last chapter as "ambivalent and ambiguous" (p. 8o). The statements noted here suggest that his later interpretations (and aspects of his original one) should be grouped with those that claim growth and irony at the end of Red Badge (see below). 
for the story in the Appleton text; the ambiguities of his interpretation are to some extent the result of an intelligent critic reading a maimed text.

Also in the first category of critics who see growth in Red Badge are still others who interpret Henry's change as an explicit movement from illusion to enlightenment. In 1925, Joseph Hergesheimer put it simply: Red Badge is the "story of the birth, in a boy, of a knowledge of himself and of self-command."52 There has been a great diversity of opinion about what precisely is Henry Fleming's insight into himself. A contemporary reviewer saw Henry's "agony of fear" turning into a "recognition of the universality of suffering." ${ }^{33}$ In 1934, Harry Hartwick claimed that the youth "reaches the conclusion that the chief thing is to resign himself to his fate, to participate in Darwin's 'survival of the fittest,' to play 'follow the leader' with Nature, and to confront this mad, implacable world with 'intestinal fortitude' and a brave smile; in one word, to become a stoic." 54 In 1951, R. W. Stallman spoke of a "spiritual change" in which Henry "confesses to himself the truth" about his previous pride and "puts on new garments of humility." ${ }^{55}$ Still later, Eric Solo-

52. Joseph Hergesheimer, Introduction to The Red Badge of Courage (New York: Knopf, 1925), p. xi.

53. N[ancy] H. B[anks], "The Novels of Two Journalists," New York Bookman, 2 (November 1895), 219.

54. Harry Hartwick, "The Red Badge of Nature," in The Foreground of American Fiction (New York: American Book, 1934), p. 27.

55. R. W. Stallman, Introduction to the Modern Library Editon of The Red Badge of Courage (New York: Random House, 1951), pp. xxxi-xxxii. This introduction was part of a longer essay that Stallman published as "Stephen Crane: A Revaluation," in Critiques and Essays on Modern Fiction, 1920-1951, ed. John W. Aldridge (New York: Ronald Press, 1952), pp. 244-69. The Critiques and Essays article contains a footnote in which Stallman points out that although Henry "progresses upwards toward manhood and moral triumph," "the education of the hero ends as it began; in self deception." Henry is "deluded" in "believing he has triumphed in facing up" to the battle of life "shorn of all romantic notions" (p. 255, n. 5). Also see Stallman's comments in his Stephen Crane: An Omnibus (New York: Knopf, 1952), pp. 221-23. These later interpretations suggest a revision of his first published analysis of Red Badge; but see Stanley B. Greenfield, "The Unmistakable Stephen Crane," $P M L A, 73$ (1958), $562-7^{2}$, esp. n. 16 , and Stallman's reply to Greenfield in a 1961 "postscript" to a reprinting of his $195^{1}$ Introduction to Red Badge, in the Norton Critical Edition of The Red Badge of Courage, ed. Sculley Bradley, Richmond Groom Beatty, and E. Hudson Long (New York: Norton, 1962), p. 254 . 
mon argued that "the standards by which Henry's development is measured are those of group loyalty rather than fear and courage." At the end of the novel, Henry's "self-interest and pride are not obliterated but transformed as he identifies himself as a member of his group." For Solomon, Henry "has learned the essence of man's duty to man, as well as the fact that life (like war) is not a romantic dream governed by absolutes, but a matter of compromises. ... At least war has shown the young soldier his true self, and the acquisition of self-knowledge is no small accomplishment." ${ }^{56}$ The list of critics with various opinions on Henry Fleming's self-insight could easily be extended.

Among these critics, Edwin Cady provides one of the most perceptive discussions of the early ironic distance between the narrator and Henry. Cady shows how, as a civilian, Henry was a "perfect neo-romantic"; how the youth's romantic egotism is undercut by "ridicule and irony"; how false are both his "irresponsibility" for his acts on the one hand and his sense of a "prophetic role" on the other; and how nature "varies with his psychic states." 57 However, Cady interprets Henry as gaining a certain understanding and modesty in the final section of the Appleton text: "In the end he sees that he is neither a hero nor a villain, that he must assume the burdens of a mixed, embattled, impermanent, modest, yet prevailing humanity." ${ }^{58}$ Cady makes some use of the manuscript; but he misjudges the importance of the deleted chapter 12 (where Henry in railing against the universe is most obviously a fool) ${ }^{59}$ and he entirely misses the interpretive significance of the excisions made in the last chapter. ${ }^{60}$

Also among the critics who see Henry as growing through self-knowledge are some who mention problems they have in interpreting the ending of the Appleton text. For example,

56. Solomon, pp. $82,87,97$.

57. Cady, pp. 122-30.

5 . Ibid., p. 142.

59. Ibid., p. 130 . Cady does recognize that this chapter "derided the naturalistic diagnosis of Fleming's condition together with Henry's Dreiser-like urge to proclaim its gospel"; but he claims that "since the relative slackness of the previous chapter makes it clear that discursive patches mar The Red Badge, it is not surprising that Crane suppressed his intended Chapter XII. He was right to do so...."

6o. Ibid., p. 141 . See note 16 , above. 


\section{Interpretive Conventions}

George Johnson wrote that Henry "supposedly learns to abide incongruity and find the world meaningful," but he also noted a "dramatic falseness" in this "implicitly optimistic close."61 Mordecai Marcus interpreted Henry as revolting against both his cowardly and fierce behavior and accepting "the perilous but unavoidable human lot." Marcus also mentioned, however, a "general weakening of interest and cohesion in the last eight chapters" and noted that the conclusion "jars slightly with some of the preceding narrative, especially with the ironic treatment of Henry," the reasons being (in part) the "suddenness of Henry's insight" and "traces of irony in the final chapter." Marcus then swept these problems aside when he confusingly argued that restoring the deleted passages would make the final chapter "quite ambiguous and would suggest that Crane regarded Henry ironically to the very end."62 That is, Marcus first complained that the ending of the Appleton text was "slightly jarring" but then rejected the solution that would remedy that "jarring."

Finally, within this large category of critics who interpret Henry as growing, there are some who see both growth and irony at the end of the Appleton text (what Pizer has called "purposeful ambivalence"). ${ }^{63}$ Whereas most of the critics I have discussed assume that once Henry grows the narrator's attitude toward him changes, this last group interprets Henry as growing in some respects but emphasizes that the narrator preserves a degree of ironic distance to the end. For example, Larzer Ziff noted that "at the very close Crane makes Henry's newly acquired cockiness so great that it becomes ambiguous when we remember his shortcomings and his rationalizations," and J. C. Levenson remarked that "residual egotism makes the ending

61. George W. Johnson, "Stephen Crane's Metaphor of Decorum," PMLA, 78 $\left(19^{6} 3\right), 251$.

62. Mordecai Marcus, "The Unity of The Red Badge of Courage," in The Red Badge of Courage: Text and Criticism, ed. Richard Lettis, Robert F. McDonnell, and William E. Morris (New York: Harcourt, Brace, 1960), pp. 193-95. Marcus wrote further that Crane's "final problem was to make us accept some intellectual self-transcendence in Henry so that our sympathies-no matter how they have been tried-will remain with him. Crane's success with this problem was, I think, only moderate" (p. 195).

63. Pizer, "Stephan Crane," p. 125. 


\section{Literary History and Reception Study}

ambiguous." ${ }^{4}$ Stanley Greenfield made the most frequently cited case for Crane's having a "duality of view" at the conclusion of Red Badge. Greenfield argued that Henry grows in both attitude and behavior and that his final evaluation of his past conduct is not undercut. "There is no vain delusion about the past," wrote Greenfield; but then he added, "As for the future-well, that is a different matter, highly ambiguous." ${ }^{65}$ As ambiguous as these critics see the ending, they always interpret a degree of growth in Henry and should properly be placed among those who make a sense of the Appleton text (indeed the intended ambiguity they find is the sense they make).

All critics in the large first category, though differing radically in specifics, do make sense of the Appleton text by interpreting Henry Fleming as growing in bravery, experience, or knowledge. A second category of critics could not make sense of the Appleton version and therefore concluded that Crane's artistic skills were limited and the writer's problems in Red Badge proved too much for him. ${ }^{66}$ One such dissenter, John Shroeder, argued that Crane's novel was "more confused than its critics have been willing to admit." He found "false directions and incoherencies" and called aspects of the book "diffuse and inchoate." Concerning the last chapter, Shroeder thought that Crane "had his own doubts about the validity of Henry's transformation." Giving a nonironic reading to the penultimate sentence, "He turned now with a lover's thirst to images of tranquil skies, fresh meadows, cool brooks-an existence of soft and eternal peace," Shroeder

64. Larzer Ziff, The American $1890 s$ (New York: Viking, 1966), p. 199, and Levenson, p. Ixxiii.

65. Greenfield, p. 571.

66. Of course, critics in this second category ultimately do make a sense of the text (e.g., by saying that Crane couldn't handle his materials or Crane didn't know what he wanted), but this is a different kind of interpretation than that of the first and third categories of critics. The second category cannot provide a coherent meaning for the story and therefore tries to explain the lack of coherence by moving "beyond" the text to the artistry of its creator (overlooking the possibility of an expurgated text as an explanation) and judging that the artistic skill was defective. Thus we have another example of evaluation being an extension of interpretation. The second group's explanation is a result of two interpretations: (1) the text makes no sense; and (2) it makes no sense because of a failure on Crane's part. Both these interpretations determine the negative evaluation of Crane's artistic ability and the text he created. 


\section{Interpretive Conventions}

commented that "Crane seems to have forgotten everything that has gone before in his own book." 67

Another dissatisfied critic, Richard Chase, wrote that themes of "spiritual death and rebirth" and of "advancing maturity" are "only sketchily there, if at all" in the Appleton text. Crane "seems half-hearted about carrying things through to the moral conclusion." Indeed, the lack of extensive rewriting does indicate that Crane was half-hearted in making the cuts, but this is not what Chase is getting at. According to Chase, Crane inclined toward dramatizing the discrepancy between Henry's illusion and actual fact but instead tried to draw a moral "in the vague and pretentious language of the last five paragraphs" (which Chase does not interpret ironically). ${ }^{68}$ James Colvert made a more detailed attack on the Appleton novel, complaining that "the problems raised in the story are not clearly defined or resolved. As a consequence the ending is confused and unconvincing." Like Shroeder and Chase, Colvert apparently believed that Crane was following the traditional genre convention of growth for his main character. With this assumption firmly in place, Colvert explained his objections:

We are told that Henry Fleming is a changed man, but we are not told how he is supposed to have met the conditions implicitly required of him in the first sixteen chapters. In the first part of the story Henry is the target of the narrator's relentless ironic criticism, scored for his delusions of grandeur, his assumption that he somehow merits a special place in the regard of the universe. And though Crane labors in the final chapter to convince us that his hero has rid himself of these delusions, the deterioration in the quality of the writing-the appearance of a tendency toward incoherence-shows that the task is too much for him. The tone shifts inappropriately, the irony is erratic and often misdirected, and the hero is permitted certain assumptions inconsistent with his previous characterization and Crane's established attitudes toward him. ${ }^{69}$

67. John W. Shroeder, "Stephen Crane Embattled," University of Kansas City Review, 17 (1950), $123^{-28}$.

68. Richard Chase, Introduction to The Red Badge of Courage (Boston: Houghton Mifflin, 1960), pp. x-xiii.

69. James B. Colvert, "Stephen Crane's Magic Mountain," in Stephen Crane: A 


\section{Literary History and Reception Study}

Colvert's criticisms of the Appleton text leave very little of Crane's artistry for us to respect. In fact, this group of critics who found only incoherence in the final chapter actually demonstrates the damaging effect of the forced excisions and not a deficiency in the author's skill.

All the interpretive chaos in Red Badge criticism, including the hesitations and confusions within individual readings, is a direct result of the expurgations made for the Appleton edition, expurgations that have allowed the text to mean many things to some critics and nothing to others. But if such critical chaos is due to a maimed text, how do we account for those critics who construct a sense for the novel in which Henry does not grow and the narrator's attitude is consistently ironic? That is, if the problems in interpreting the Appleton text are caused by the missing passages, how can a small third category of Crane critics not only interpret that text but, in fact, provide a sense that closely resembles what Crane originally presented in the manuscript? How did Charles Walcutt and John Berryman, for example, interpret Henry as not growing and the narrator's attitude as ironic toward Henry throughout? ${ }^{70}$

Collection of Critical Essays, ed. Maurice Bassan (Englewood Cliffs, N.J.: Prentice-Hall, 1967 ), pp. 95-96, emphasis added.

7o. Charles Walcutt, American Literary Naturalism, A Divided Stream (Minneapolis: University of Minnesota Press, 1956), pp. 74-82, and John Berryman, "Stephen Crane: The Red Badge of Courage," in The American Novel: From James Fenimore Cooper to William Faulkner, ed. Wallace Stegner (New York: Basic Books, 1965 ), pp. 86-96. Walcutt's consistently ironic interpretation has been seconded by Jay Martin, Harvests of Change (Englewood Cliffs, N.J.: Prentice-Hall, 1967), pp. 64-65; Clark Griffith, "Stephen Crane and the Ironic Last Word," Philological Quarterly, 47 (1968), 85-86, 88-9o; and in part by Miller, An Armed America, p. 72 , and Chase, p. xv. However, "most critics have not accepted such an extreme view of Crane's attitude toward Fleming" (Pizer, "Stephen Crane," p. 124). Berryman's interpretation might at first seem to be closer to that of Greenfield (intended ambiguity) or Colvert (unintentional confusion) than to Walcutt's. Berryman admitted, "I do not know what Crane intended. Probably he intended to have his cake and eat it too-irony to the end, but heroism too" (p. 9o). Berryman went on, however, to tip the balance more toward irony: "It seems impossible not to conclude that the splendid burst of rhetoric with which the novel concludes is just that in part-a burst of rhetoric-and that Crane retained many of his reservations about his hero" (p. 91). Finally, the force of the hedging "in part" seems gone entirely when Berryman concluded that "we are left after all with a fool..." (p. 91), making Berryman's interpretation approach close to Walcutt's (as Miller recognized in An Amed America, p. 72). 
One demonstrable answer is the critic's use of modal conventions-stylistic and thematic conventions that convey a particular interpretation of experience. For a critic who claimed that the modal conventions of naturalism governed Red Badge, the possibility of Henry's self-betterment would be very remote indeed, since the youth would be viewed as a mere pawn of external and internal forces. Thus, in American Literary Naturalism, $A$ Divided Stream, Walcutt argued that Crane is a naturalist who "makes us see Henry Fleming as an emotional puppet controlled by whatever sight he sees at the moment." Guided by the modal conventions of naturalism, Walcutt decided that Henry "has not achieved a lasting wisdom or selfknowledge" and therefore fails to grow. ${ }^{71}$ But apparently the use of modal conventions is not sufficient in itself to determine an interpretation that sees Henry not growing at all; Pizer, for example, also invoked modal conventions in his interpretation. ${ }^{72}$ Nor are authorial conventions enough: Marston LaFrance was as sensitive as Berryman to ironic conventions throughout the Crane canon, yet he still interpreted Henry as attaining "authentic self-knowledge and a sense of manhood after long and fierce battles with his own moral weaknesses." 73

I can, however, point to another literary convention and its use in Red Badge criticism-a convention of narrative consistency that guides the telling of stories in novels and related genres. ${ }^{74}$ One corollary of this regulative convention can be roughly stated: There should be no radical (unexplained) change in the attitude of the narrator toward his protagonist. What Berryman

71. Walcutt, pp. 79, 82 .

72. Pizer, Realism and Naturalism, pp. 12-14, 24-32.

73. Marston LaFrance, $A$ Reading of Stephen Crane (London: Oxford University Press, 1971), p. 123 .

74. This convention can be viewed as a traditional genre convention turned regulative. Its form is generic in that it holds within narrative genres, but its specific content develops during the reading of particular texts. For example, novel readers expect that the narrator's attitudes toward characters or the probabilities within the created world will remain the same (unless reasons are explicitly or implicitly given to account for changes); but each individual novel establishes what the actual attitudes or probabilities will be in that particular fiction and its telling. Thus the convention of narrative consistency is an example of a traditional genre convention that makes possible conventions (or contracts) within individual works. 
and Walcutt have done in their interpretations of the Appleton text is to use this narrative convention to supply what "wasn't there"; they merely extended to the conclusion the narrator's ironic attitude established early in the novel. For example, Berryman noted that a "pervasive irony is directed toward the youth-his self-importance, his self-pity, his self-loving war rage." As a result of his sense of this early irony, at one point in his reading of the last chapter, Berryman protested, "But then comes a sentence in which I simply do not believe": "He turned now with a lover's thirst to images of tranquil skies, fresh meadows, cool brooks-an existence of soft and eternal peace." This sentence, which Shroeder took so literally, is interpreted by Berryman on the basis of the ironic conventions of the earlier chapters. ${ }^{75}$ Walcutt was even more explicit about how his reading of the earlier sections determined his refusal to interpret Henry as growing in the final chapter: Henry's self-evaluation in the final section is "a climax of self-delusion. If there is any one point that has been made it is that Henry has never been able to evaluate his conduct." 76

This last account of how a small number of critics could interpret the expurgated Appleton text ironically to its end also helps explain what happened with the critics who found the text incoherent: they simply refused to extend into the final chapter the interpretive conventions established early in the novel. For these dissatisfied critics, a genre convention that they assumed Crane to be following at the end (growth through war experience) was at odds with a convention developed early in the novel (ironic distance), and they resolved the inconsistency (which they had supplied in responding to a mutilated text) by judging Crane's artistic skill at fault. But then what happened with the large first category of critics, most of whom made a nonironic, "coherent" sense of the ending? We could simply say that they ignored relevant discrepancies in the story (relevant, that is, according to the terms of their own interpretations) which cannot be conven-

75. Berryman, pp. 89, 91 .

76. Walcutt, p. 81. Cf. Michael J. Hoffman, The Subversive Vision: American Romanticism in Literature (Port Washington, N.Y.: Kennikat Press, 1972), pp. 138-39; and Clinton S. Burhans, Jr., "Judging Henry Judging: Point of View in The Red Badge of Courage," Ball State University Forum, 15 (1974), 45-48. 


\section{Interpretive Conventions}

tionally accounted for without the manuscript evidence. ${ }^{77}$ But we could also further surmise that because their attention was deflected by the length of the battle descriptions between the obvious early narrative irony and the last chapter, these critics were able to accept a radical change in the narrator's attitude toward Henry Fleming; and because of the traditional convention that heroes in realistic war novels grow (and that outward heroism in battle indicates internal maturation), they could accept Henry as growing.

In this way the interpretations of the Appleton text can all be accounted for by the ability (or inability) of critics to invoke traditional and regulative conventions. Only those most sensitive to the conventions Crane was employing could come close on the basis of the expurgated Appleton text to a knowledge of his originality in transcending the tradition of the realistic war novel. But even these critics could not fully appreciate Crane's achievement because significant scenes are irretrievable without the manuscript. ${ }^{78}$

My concluding perspective on Red Badge criticism focuses on the convention of irony, an interpretive convention that has functioned in complex and subtle ways in attempts to make sense of the Appleton text. All Red Badge critics invoke an ironic convention to interpret the first part of the story, but the largest number drop the convention by the last chapter as they interpret Henry as growing and the narrator's attitude toward him as changing. Those that continue to invoke the convention do so in three different ways. Some critics (Colvert, Chase, Shroeder) do not use the ironic convention consistently to the end, "seeing"

77. See Binder, "The Red Badge Nobody Knows," pp. 24-26.

78. Lost to the readers of the Appleton text are such scenes as those in the original chapter 12, where Crane masterfully undercuts Henry's cosmic selfjustifications. The power of the thoughts expressed in this chapter has encouraged some critics to underestimate the importance of the character expressing those thoughts-see O. W. Fryckstedt, "Henry Fleming's Tupenny Fury: Cosmic Pessimism in Stephen Crane's The Red Badge of Courage," Studia Neophilologica, 33 (1961), 265-81. Also lost to Appleton readers is the final Jimmie Rogers scene (see n. 16, above). Thus Berryman (pp. 9o-91) could wonder why Crane's deep concern for "Human Kindness" plays no part in the Appleton Red Badge. In the manuscript, which contains the final Jimmie Rogers episode, concern for others (or lack of it) does play a part. 
residual irony only in places and interpreting Henry as achieving an undeserved or incoherent self-knowledge. Others (Greenfield, Ziff, Levenson) agree that Henry grows in the Appleton text, but by continuing to invoke the ironic convention consistently, they resolve potential textual problems through the use of a popular modern interpretive convention, the "discovery" of purposeful ambivalence: Crane intended growth and irony, a positive change in Henry with an apparent residue of continued self-delusion. Still other critics (Walcutt, Berryman) use the ironic convention to eliminate any growth in Henry, resolving all potential textual problems by positing a consistent ironic attitude in the narrator which undercuts any apparent change in the main character.

The incomplete state of the Appleton ending requires critical choices in the use of interpretive conventions, choices that force critics to "write" their own texts that they call The Red Badge of Courage. One group writes a traditional realistic war novel of the nineteenth century; another constructs an inconsistent artistic failure; another makes a twentieth-century ironic tale of purposeful ambivalence; and still another creates a story that comes surprisingly close to the experimental novel that Crane actually intended. The interpretive work of each critic can best be revealed through the kind of literary history I have illustrated in these last two sections. Such an intraliterary history of reception provides a necessary supplement to the current histories of literary production and consumption. 